\title{
The food web in Red Wharf Bay (North Wales) with particular reference to young plaice (Pleuronectes platessa)
}

\author{
Charles T. Macer \\ Fisheries Laboratory, Lowestof, England
}

\begin{abstract}
KURZFASSUNG: Die Nahrungskette in der Red Wharf Bucht (Nord-Wales) mit besonderer Berücksichtigung junger Schollen (Pleuronectes platessa). Okologische Aspekte und qualitative Gesichtspunkte der Ernährung von Pleuronectes platessa und Limanda limanda aus der Red Wharf Bucht wurden untersucht. Die jungen Schollen treten in der Bucht in der Zeit von April bis Juli (oder August) auf; von August bis zum Winter beträgt die monatliche Verlustquote ungefähr $40 \%$. Zunächst ist die Verbreitung der Jungfische auf die Ebbe-Linie beschränkt. Jungfische der Kliesche erscheinen von Juni an; ihre Verlustrate beträgt ungefähr $44 \%$ pro Monat. Im Sommer wachsen die beiden Arten schnell; in der Zeit von November bis April ist die Wachstumsgeschwindigkeit jedoch verringert. Bei Arten mit ähnlichem Nahrungsverhalten wurden Unterschiede hinsichtlich der Tiefenverteilung festgestellt, so daß sich die Areale der Arten nur teilweise überdecken. Die Klieschen haben ein Nahrungsspektrum, das dem der Schollen aus der 0-Gruppe ähnelt, doch bestehen, wie eingehende Untersuchungen gezeigt haben, bestimmte Unterschiede. Sowohl Schollen als auch Klieschen der 0-Gruppe wurden von anderen Tieren, vor allem Artgenossen (Tiere der I-Gruppe), gefressen. Markierungsexperimente zeigten, daß Jungschollen der 0-Gruppe - zumindest im Sommer und Herbst - in das flachere Wasser zurückkehren, nachdem sie markiert und in tieferes Wasser ausgesetzt worwaren.
\end{abstract}

\section{INTRODUCTION}

Because fish stocks in European waters are becoming increasingly exploited and many of them are showing clear signs of overfishing, there is great interest in the factors which determine their productivity. The mechanisms which control year-class strength, that is, the survival from eggs to the recruit fish, are of special interest. The survival is variable but very low, the order of magnitude being about 1 in 20,000. Most of the mortality probably takes place in the larval and juvenile stages, and thus it might be practicable to rear young fish obtained from hatcheries or from nursery areas, with the object of reducing the natural mortality and, possibly, increasing growth rate. It is important, therefore, to have a full understanding of the ecology of these fish up to the time of recruitment, and especially during their first year of life.

Red Wharf Bay on the coast of Anglesey is one of the nursery areas which support populations of young fish resulting from spawning about fifteen $\mathrm{km}$ to the north-east, 
off Great Ormes Head. Figure 1 shows the location of the bay and the inset portion shows the bay in relation to the Great Orme spawning ground, which is cross-hatched. This latter area is a spawning ground for several species of fish but principally for plaice (Pleuronectes platessa) and dabs (Limanda limanda), and these two species are found in abundance in Red Wharf Bay. A team from the Lowestoft Laboratory has

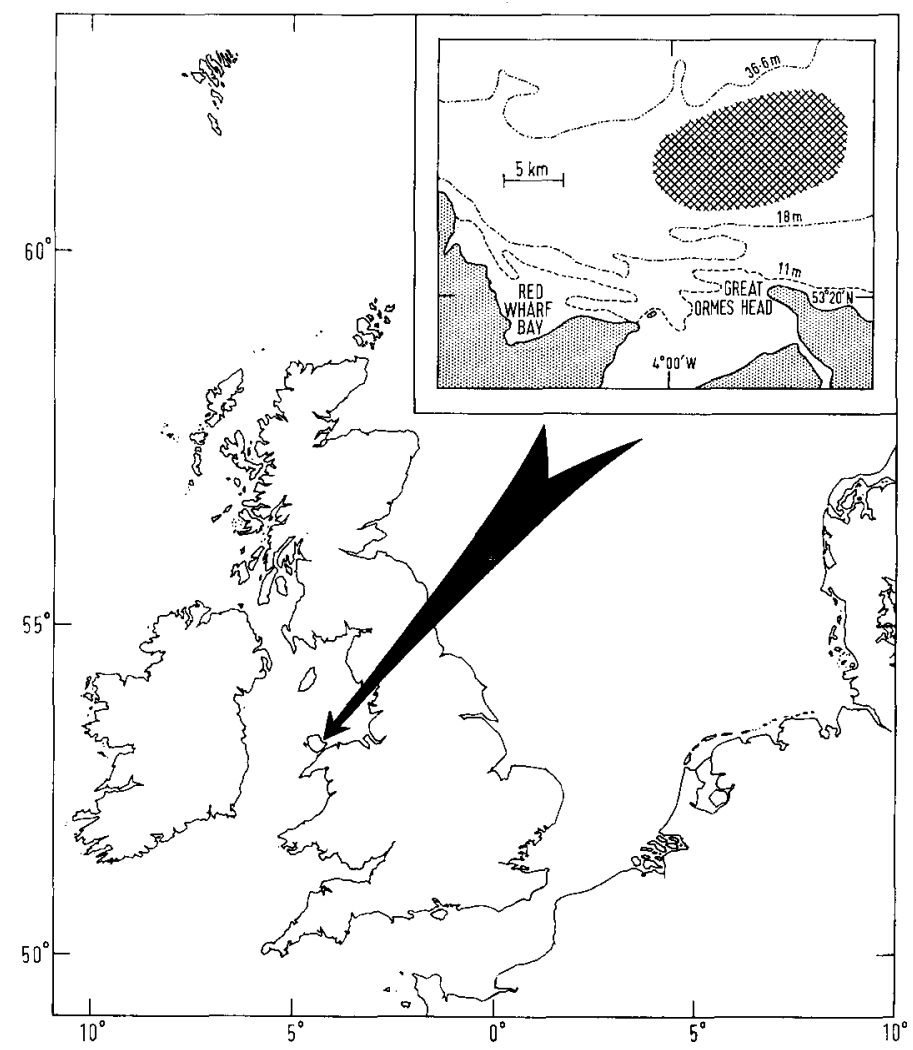

Fig. 1: Location of Red Wharf Bay (arrowed). Inset is an enlarged view of the bay; the centre of the Great Orme spawning ground is shown cross-hatched

been investigating plaice spawning off the Great Orme, following the process from the spawning adults, through the eggs and larvae, to the juveniles on the beaches. A study of the food web is being made in Red Wharf Bay, with special reference to possible competitive mechanisms which might affect the young plaice. The initial work reported here has been concerned mainly with qualitative studies, which will lead, it is hoped, to a more detailed evaluation of the energy flow through the system.

Since 1964 regular monthly samples have been taken with $4 \mathrm{~m}$ and $2 \mathrm{~m}$ beam trawls, a $0.1 \mathrm{~m}^{2}$ van Veen grab, and a bottom plankton sampler, along five transects (T1 to T5, see Fig. 10) which started at low-water mark and extended seawards in a north-easterly direction. The seaward limit of the transects depended on that of the 
O-group plaice, the latter being determined by a series of trawl hauls parallel to the shore in various depths. A 1.5-metre push-net was used at low-water at the west end of the bay (T1). Before describing the food web, the general ecology of the bay will first be considered.

\section{GENERAL ECOLOGY}

The bay is sheltered from the prevailing wind (south-west) and the benthos is of the "boreal offshore muddy sand" type (Jones 1950). Many of the characteristic animals, such as Echinocardium cordatum, Ophiura texturata, Philine aperta, Abra alba, Nucula turgida and Tellina fabula, are not eaten by the fish to any great extent, but others such as Pectinaria koreni, Nephtbys spp., Pbyllodoce spp. and Ampelisca brevicornis are preyed upon heavily. Pectinaria is particularly abundant and concentrations of young worms of up to 7800 per $\mathrm{m}^{2}$ have been recorded. Plankton is important in that it often forms the food of the newly metamorphosed flatfish, and a characteristic feature is the presence of larvae of the polychaete family Spionidae (chiefly Polydora ciliata).

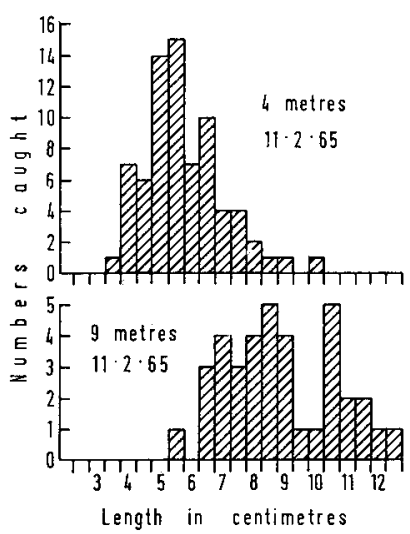

Fig. 2: Length-frequency distributions of 0 -group plaice caught in two depths, 4 and $9 \mathrm{~m}$

About twenty-five species of fish are found, but numerically three species predominate in the beam-trawl catches - plaice, dabs and gobies (Gobius minutus) as shown in Table 1, in which the percentage compositions of species caught in the beam trawl and in the pushnet are given separately. Comparison with an otter trawl has shown that the beam trawls used are relatively inefficient at catching pelagic fish such as herring, sprat and mackerel, and also whiting and the larger flatfish; the beam trawl will thus tend to underestimate the numbers of these fish. The push-net was nearly always used at low water of neap tides and here ' 0 -group' plaice (those that are in their first year of life) form about $70 \%$ of the total. It is only on large spring tides that 0 -group dabs are caught at low-water mark in the push-net. Decapods are 
abundant and are represented chiefly by Crangon vulgaris, Carcinus maenas, Portunus spp., Eupagurus sp., Corystes cassivelaunus and Hyas sp.

Each year, plaice of the new brood make their first appearance in the bay in late April or May; their length range is then from about ten to twenty millimetres and many have not yet completed metamorphosis. At this time, they are found very close inshore in a few centimetres depth, their distribution ranging from the water's edge to about two metres. In this location they are, to a large extent, segregated from potential predators such as larger plaice and dabs, though there may be additional environmental hazards such as wave action. As seen in Table 1, 0-group plaice comprise over $70 \%$ of the fish fauna in this shallow-water zone, sharing it mainly with gobies, sand eels (Ammodytes spp.), and weevers (Trachinus vipera). In addition, Crangon and a few Carcinus also live in this zone.

Table 1

Species composition of catches in beam trawl and pushnet

\begin{tabular}{|lcc|} 
& \multicolumn{2}{c}{ o\% of catch in } \\
Species & Beam trawl & Push-net \\
\hline Limanda limanda "0-group" & 3.3 & 1.6 \\
Pleuronectes platessa "O-group" & 19.0 & 70.0 \\
Gobius minutus & 17.0 & 4.9 \\
Solea lutea & 9.2 & - \\
Limanda limanda "I-group" & 7.2 & 0.02 \\
Pleuronectes platessa "I-group" & 7.2 & 5.8 \\
Callionymus lyra & 1.6 & - \\
Trachinus vipera & 0.9 & 1.9 \\
Ammodytes spp. & 0.9 & 14.2 \\
Syngnathus spp. & 0.6 & 0.9 \\
Solea solea & 0.5 & 0.09 \\
Raja clavata & 0.4 & - \\
Gadus luscus & 0.3 & - \\
Trigla sp. & 0.3 & - \\
Agonus cataphractus & 0.2 & 0.1 \\
Gadus merlangus & 0.2 & - \\
Arnoglossus laterna & 0.07 & 0.05 \\
Platichthys flesus & 0.02 & 0.4 \\
Others & 1.0 & \\
\hline
\end{tabular}

As the plaice grow larger some tend to move into deeper water and in the winter their distribution extends into a depth of about $14 \mathrm{~m}$, though some of the smaller ones are still caught in the push-net at low-water mark. The variation in size in different depths is illustrated in Figure 2, which shows the length distributions of 0 -group plaice caught in depths of 4 and $9 \mathrm{~m}$ in February 1965. Presumably this mechanism helps to reduce intraspecific competition and cannibalism.

Figure 3 shows the numbers of 0 -group plaice caught per standard tow at several transects, throughout the year, for the 1964 and 1965 year-classes. Basically, the data may be divided into three parts (as indicated by the broken lines) - there is an increase in numbers until July or August, a decrease from September to December 
and thereafter a gradual increase. The initial increase indicates recruitment and since the later recruits are much larger than those which arrive first, they must have metamorphosed offshore and somehow found their way into the bay; BREGNBALLE (1961)

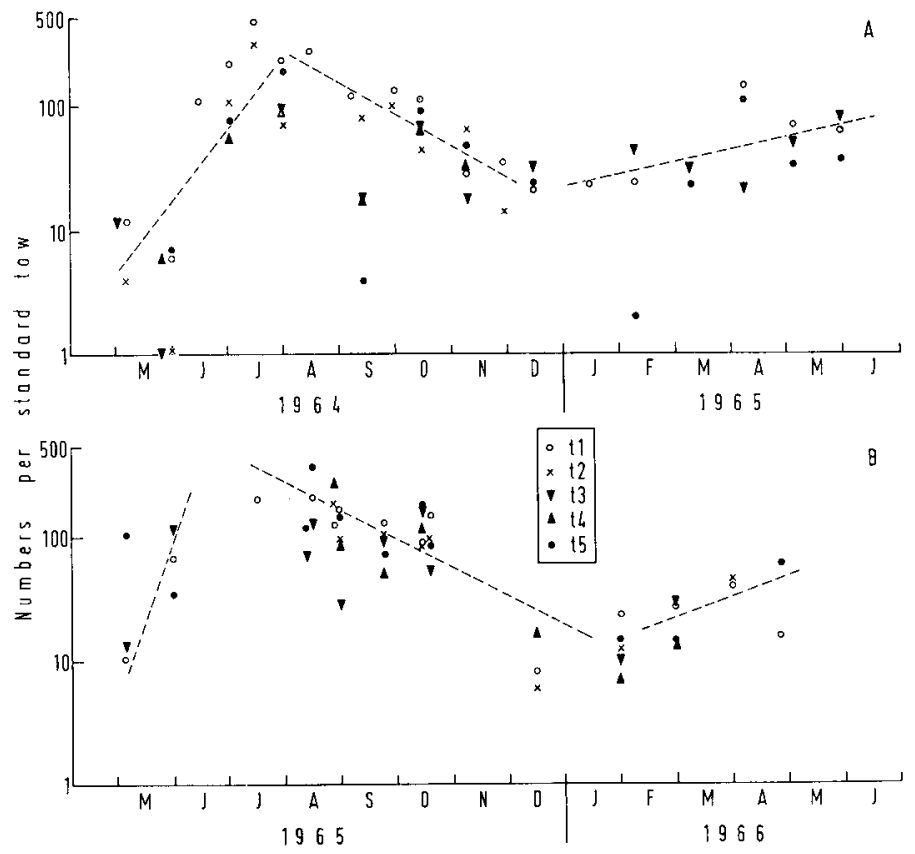

Fig. 3: Numbers of 0-group plaice of the 1964 and 1965 year-classes caught per standard tow at five positions in the bay

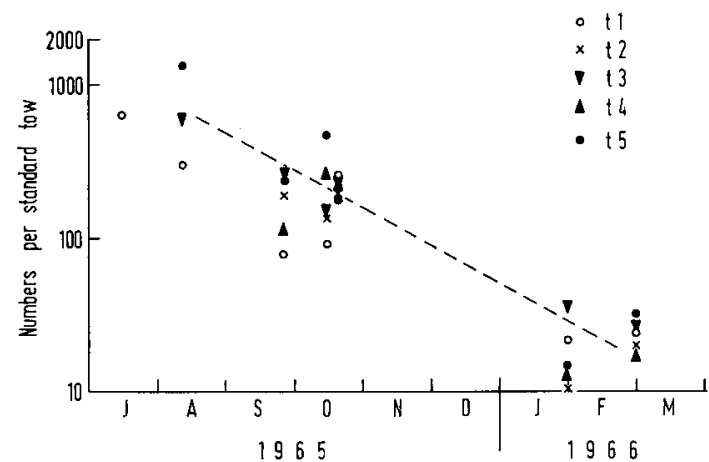

Fig. 4: Numbers of O-group dabs of the 1965 year-class caught per standard tow at five positions in the bay

came to a similar conclusion for young plaice at Kysing Fjord. The decrease represents a monthly reduction of about $40 \%$, due largely to predation; after December, the data indicate an immigration into the bay. Work in progress on changes in gear 
efficiency during the year will probably slightly modify the pattern but not the overall trends. The mortality rate is similar to that found by Pearcy (1962) for juvenile flounders (Pseudopleuronectes americanus).

The new brood of dabs does not arrive until June and they never penetrate as far into the shallows as do the plaice. Figure 4 shows the numbers in standard tows
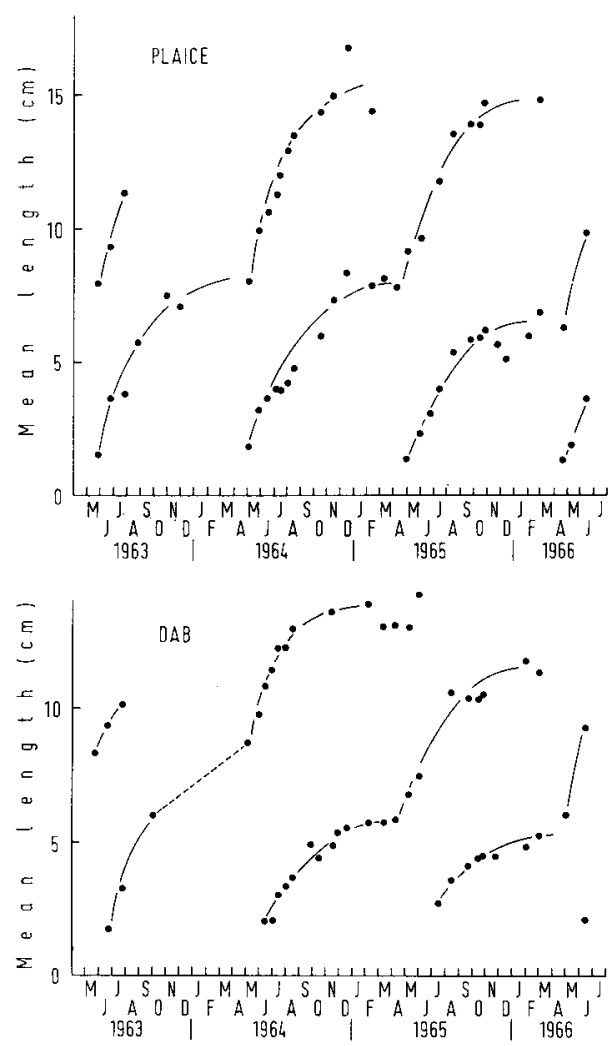

Fig. 5: Growth of plaice and dabs in the bay

for the 1965 year-class, that for 1964 being inadequately sampled. The data suggest that recruitment occurs over a shorter period than in the plaice; the rate of decline in numbers is about $44 \%$ per month.

Figure 5 shows the growth of 0 - and I-group plaice and dabs from May 1963 to June 1966. It can be seen that in both species growth is rapid in summer but slows markedly in winter. In the plaice, the growth of the 1965 year-class was not as good as that of the previous two year-classes. With dabs, the 1963 year-class grew faster in its first two summers than did the 1964 year-class. 


\section{GENERAL FEEDING PATTERNS}

The foregoing is an outline of some of the general ecological features which are relevant to food chains in the bay. At present, only the third trophic level (chiefly fish) has been studied, and for a preliminary rapid analysis of feeding the data are presented by the "occurrence" method. For each category, the percentage of stomachs containing food in which it occurred is recorded. This method has limitations in quantitative work but is satisfactory in assessing feeding on a qualitative and comparative basis.

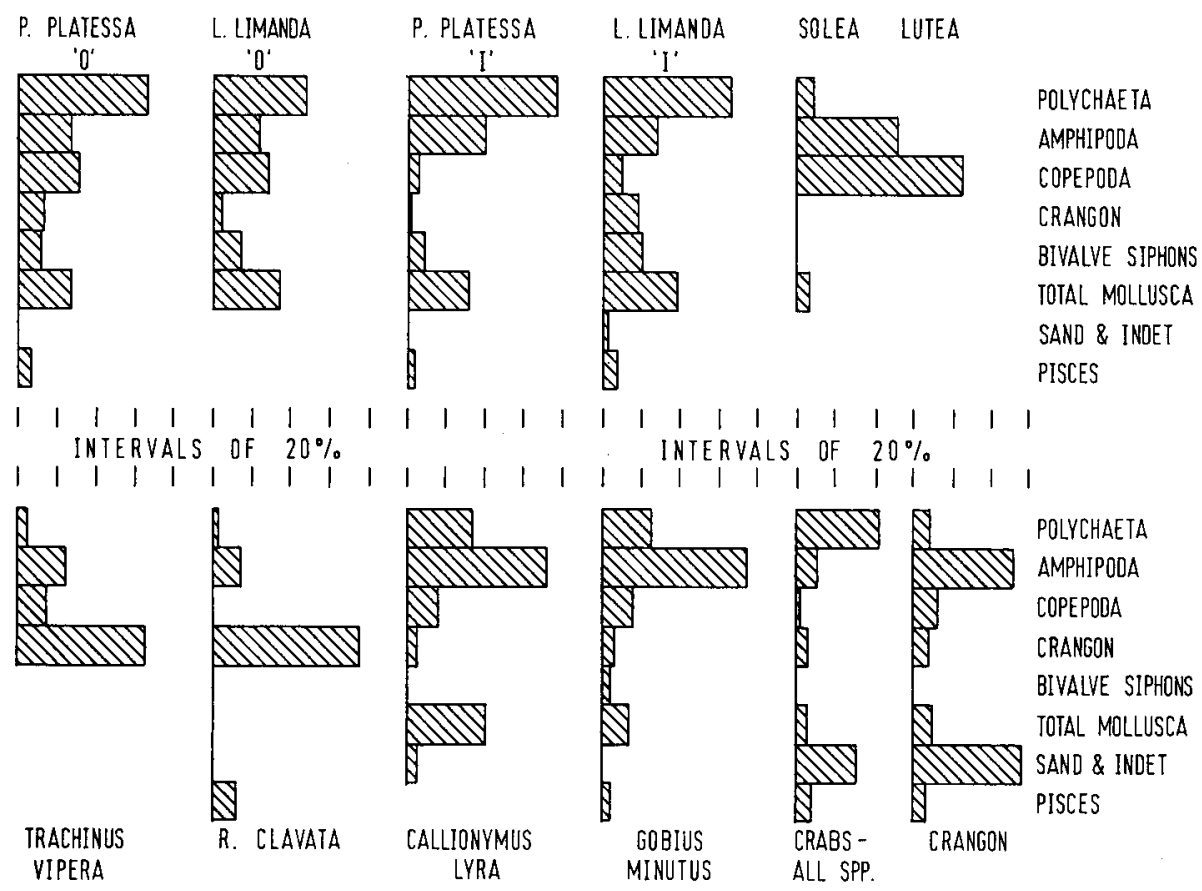

Fig. 6: Diet of the most abundant predators from May 1964 to April 1965

Figure 6 shows the main types of food eaten by the most abundant predators from May 1964 to April 1965. Plaice and dabs, both O- and I-group, have similar food patterns in which polychaetes predominate, although amphipods, lamellibranchs and copepods (chiefly harpacticoids and cyclopoids) are also important. In Gobius and Callionymus lyra, amphipods occur most frequently in the stomachs, whilst Trachinus and Raja clavata prey largely on decapods, mainly Crangon but also crabs in the latter fish. Solea lutea feeds on harpacticoids and, to a lesser extent, on amphipods. Many Crangon and crabs had empty stomachs and, in those that did contain food, the contents were often unrecognizable or fragmentary. However, in Crangon, remains of amphipods predominate and in crabs, remains of polychaetes. Thus, as far as O-group plaice are concerned, only I-group plaice and both year-groups of dabs seem 
to have similar feeding habits. A more detailed examination of feeding in these fish will now be given.

\section{THE DIET OF PLAICE AND DABS}

There are, of course, differences in feeding from year to year and this is especially true of the young plaice when they first arrive in the bay. Figure 7 shows the composition of the diet of 0 -group plaice of similar lengths $(10-25 \mathrm{~mm})$ when they were first caught in each year from 1963 to 1966 . In this figure, the ordinate is the percent-

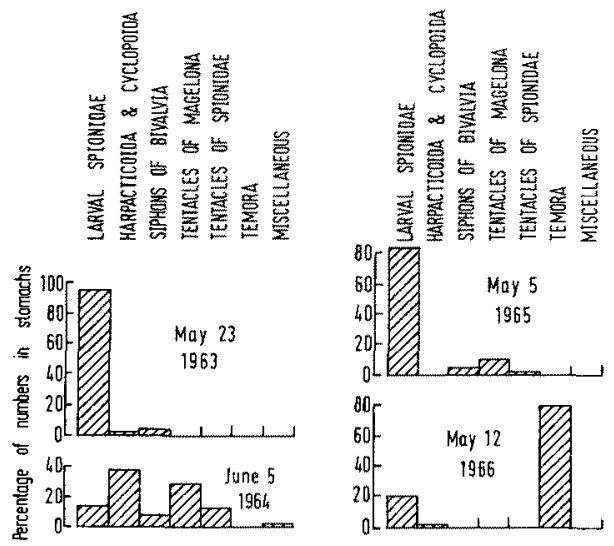

Fig. 7: Diet of newly-arrived O-group plaice from 1963 to 1966

age of total numbers in the stomach. In 1963 (the numbers here are approximate), the initial diet consisted almost entirely of larval Spionidae and, although this was true in 1965, tentacles of Magelona papillicornis were also taken in that year. In 1964, many harpacticoids and cyclopoid copepods were eaten, but in 1966 the stomachs were packed with the calanoid copepod Temora longicornis. In general, the biomass of benthos at low-water mark (where the plaice live at first) is very low compared with that further offshore. It is thus interesting to find that the plaice will feed to a large extent on plankton (probably bottom plankton). According to returns of sea-bed drifters (RAMSTER 1965), bottom currents are onshore in this area and it is thus possible that bottom plankton may tend to be concentrated in the shallows, so providing a favourable environment for the plaice.

Figure 8 shows the stomach contents of plaice and dabs in more detail and some interesting differences are apparent. Considering first the most frequently occurring food item, polychaetes, it can be seen that whole adult worms, rather than tentacles or larvae, occur more often in the older fish than in the younger ones. There is a marked difference between plaice and dabs, because in the former the predominant polychaete is Nepbtbys, whereas in the latter it is Pbyllodoce or Pectinaria. Larval Spionidae and tentacles of Magelona form the main polychaete food of the younger plaice and dabs. 
Ampelisca is the predominant amphipod in all four groups and is most frequently found in stomachs of I-group plaice.

Batbyporeia spp. and isopods were not found in 0-group dabs but Caprellidae were found exclusively in them and in older dabs. There are also differences with regard to predation on Crangon; whereas the frequency of occurrence of this species

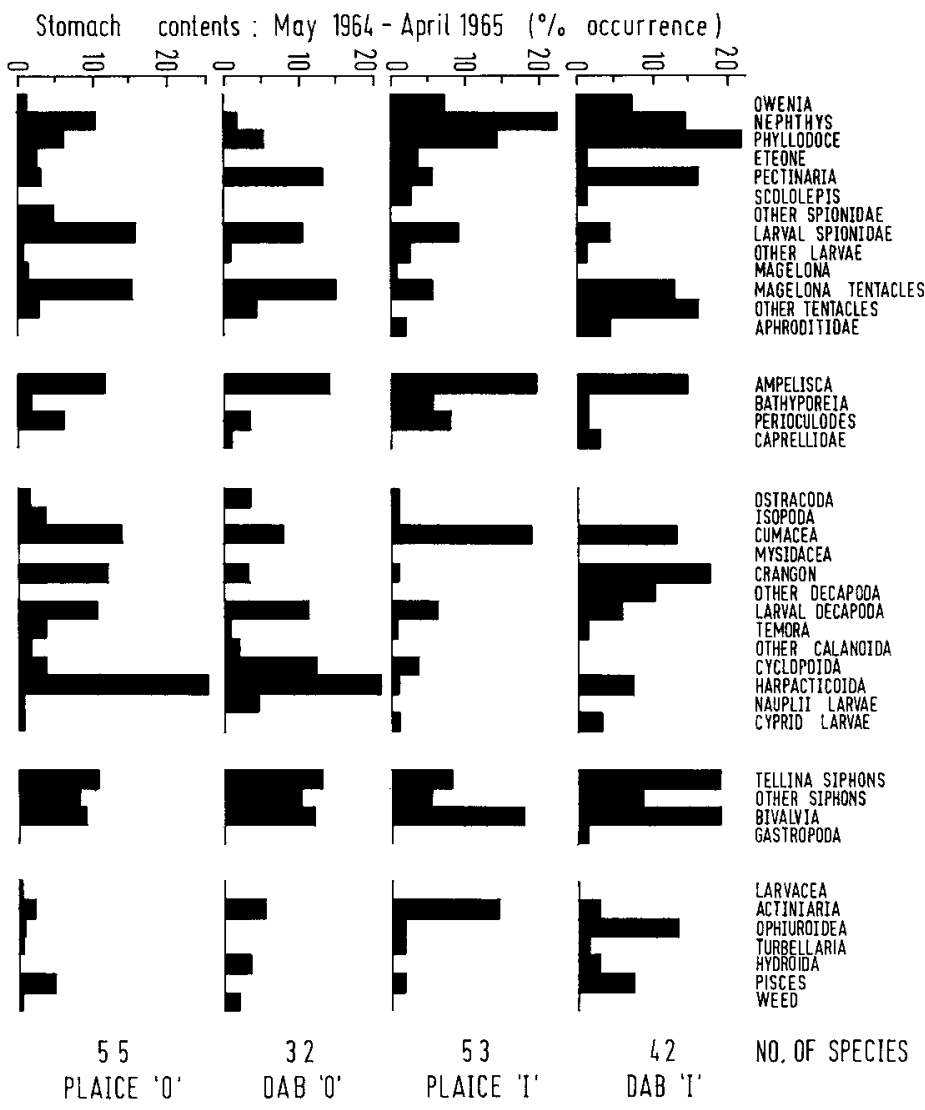

Fig. 8: Diet of plaice and dabs in detail from May 1964 to April 1965

increases from younger to older dabs, the converse is true for plaice. Other decapods (mainly crabs) are found exclusively in older dabs. Cyclopoid and harpacticoid copepods are more often found in younger plaice and dabs than in the older fish, with cyclopoids (mainly Cyclopinoides littoralis) more frequent in dabs than in plaice. The younger fish also tend to eat lamellibranch siphons rather than the adult molluscs. Larvacea, ophiuroids, Turbellaria and fish were all found in 0-group plaice but not in O-group dabs. In the older fish, differences are apparent for Actinaria (more common in plaice) and ophiuroids (more common in dabs).

The total numbers of different food species found in the stomachs are also shown 
in the figure, and it is evident that both 0 - and I-group plaice have a more varied diet than do dabs. The surprising aspect of the stomach contents is the relative scarcity of adult lamellibranchs, since they are abundant in the bay and form the main diet of adult plaice and dabs off the Cumberland coast (Jones 1952). In Red Wharf Bay, however, they are not abundant even in the stomachs of larger fish (II- and III-group), and it may be that, where polychaetes are numerous, they are preferred.

This initial survey of feeding has shown that none of the food spectra are identical. Where they show some similarity, differences in distribution perhaps help to minimize over-exploitation of a common food supply and this is illustrated by three pairs of species previously referred to in Figure 6. In each of these pairs, although the diet is similar, one of the species has a much wider depth distribution than the other. Thus, considering plaice and dabs, Gobius and Callionymus, Trachinus and $R$. clavata, the first mentioned of each pair occurs over a wide range of depth and is caught in both the beam trawl offshore and the push-net at low-water mark. The others are absent or infrequent in the push-net catches (Table 1) and are found well below lowwater mark.

The high mortality rate of 0 -group plaice and dabs, previously referred to, is presumably caused chiefly by predation. 0 -group plaice have been found in stomachs of I-group plaice (up to $20 \%$ in some samples) and Trachinus, whilst O-group dabs have occurred in stomachs of $\mathrm{O}$ - and I-group plaice, and I-group dabs. Fish remains are also found in the stomachs of Crangon, Portunus and Carcinus, though to no great extent; it is possible that in these cases the fish may have died from other causes before being eaten. $R$. clavata, Gobius, and Agonus are other species in which fish have been recorded in the stomachs. Thus it should be possible, by providing a predator-free environment, to greatly increase the survival rate of young plaice. There was good evidence that a programme of predator control was effective in increasing survival in salmon (FOERSTER \& RICKER 1941), though the feasibility of such programmes depends to a large extent on economic considerations. It is also important to consider changes in biomass and production (SAILA, HorToN \& BerRy 1965).

\section{MOVEMENTS OF PLAICE}

An important question in investigating feeding of fish is whether the populations are restricted to definite areas or move about freely in search of food. In the case of O-group plaice, this was investigated by a marking experiment which my colleague J. D. RILEY and I conducted jointly in late August 1965. The plaice were marked by injecting a small amount of coloured liquid latex under the skin on the unpigmented side (RILEY 1966). At about low-water mark, at each of three positions in the bay (east end - 'T5', west end - 'T1', and centre - 'T3'), about 3000 plaice were marked and released, different colours being used at each position; the distance between positions is about two $\mathrm{km}$. In addition, from 12 to 16 August 5400 plaice were caught at position T1, marked with a different colour (green) and released at a position in the centre of the bay about $3.5 \mathrm{~km}$ from low-water mark (Fig. 9). It had been established, immediately before the release, that, as was usual at that time of year, 


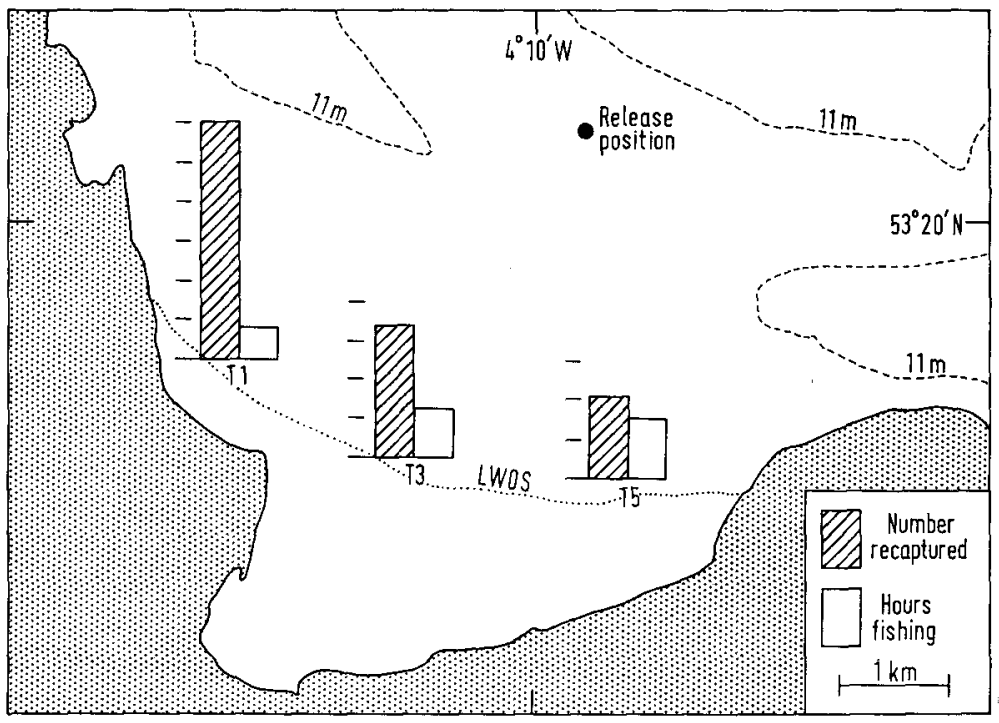

Fig. 9: Recaptures at three positions of 0 -group plaice caught at position $\mathrm{T} 1$, marked with green latex, and released offshore. The ordinate on each histogram is in units of 10

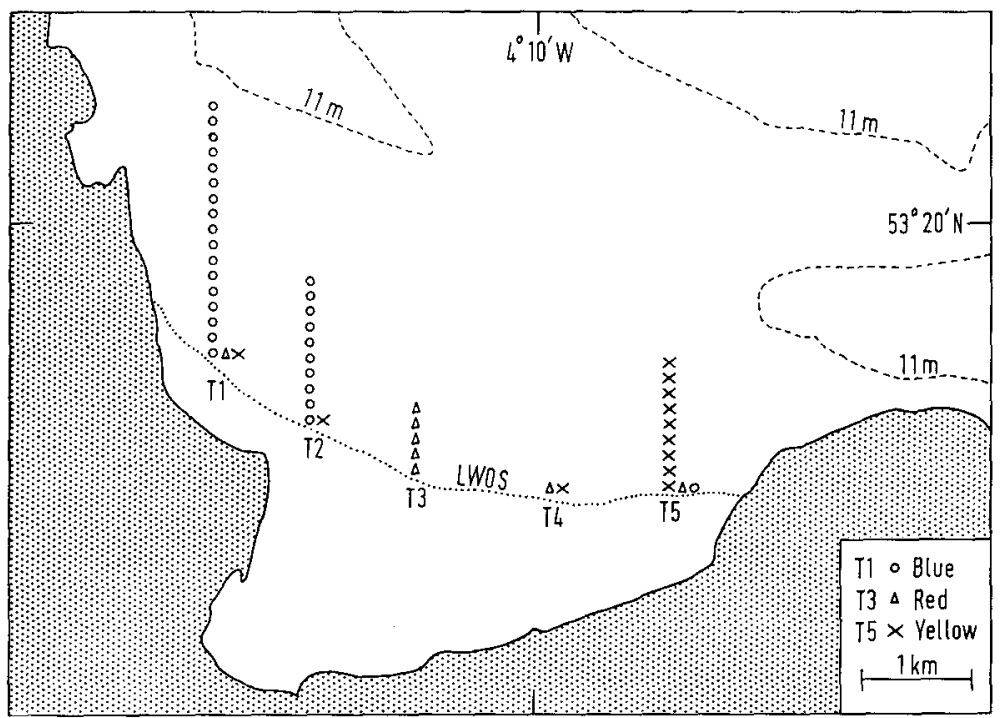

Fig. 10: Recaptures at five positions of 0-group plaice marked with coloured latex and released where caught at positions $\mathrm{T} 1, \mathrm{~T} 3$ and $\mathrm{T} 5$

O-group plaice were not to be found at that position but were living in shallower regions towards low-water mark. After the releases, surveys for the marked fish were carried out by trawling in the release positions and also at two intermediate transects 
('T2' and 'T4'). At each transect position the hauls were either parallel to the shore in the region of low-water mark or at right angles to the shore, running out northeastwards as previously mentioned. The great majority of recaptures were made in August, September and October, when most of the 0-group plaice are found between low-water mark and $5 \mathrm{~m}$.

The recaptures of the fish marked green and released offshore are given in Figure 9, which shows, for positions T1, T3 and T5, the numbers of recaptures and the number of hours spent surveying from 20 August to 23 December 1965 (the week in which the last recapture occurred). It can be seen that more of the marked fish were recaught at $\mathrm{T} 1$ - the original position of capture - than elsewhere, and three possible reasons for this are suggested: (a) a "homing" reaction; (b) a general movement of plaice to position $\mathrm{T} 1$; and (c) a lower mortality rate at T1 compared with the other positions.

Some light is thrown on these possible explanations by a consideration of the recaptures of plaice marked and released where caught (Fig. 10). These releases lasted from 17 to 29 August and the figure shows the recaptures from 26 October 1965 to 3 February 1966, when the last recapture occurred. Those at T1 were marked blue, those at T3 red, and those at T5 yellow. It can be seen that very few of the recaptures were made outside the area of release. Out of twenty-eight blue recaptures, ten had moved a short distance to T2 and only one had moved across the bay to T5. Of the releases at $\mathrm{T} 3$, eight were recaptured, five in the release area and one each at $\mathrm{T} 1, \mathrm{~T} 4$ and T5. Twelve fish marked at T5 were recaptured, nine in the release area, one at $\mathrm{T} 4$ and two across the bay at $\mathrm{T} 1$ and $\mathrm{T} 2$. Thus there appears to be little lateral movement of plaice and no general movement towards T1. There were more recaptures per hours' fishing at T1 and T2 than at the other positions, suggesting that the greater catches of green-marked fish at T1 were not due to "homing" but to differential mortality. However, the large number of green-marked fish recaught at T1 perhaps calls for further investigations into the ability of young plaice to recognize specific areas of a bay. A fuller account of these marking experiments is in preparation.

\section{SUMMARY}

1. About twenty-five species of fish occur in Red Wharf Bay; plaice, dabs and gobies predominate in the beam-trawl catches. O-group plaice comprise about $70 \%$ of the catch in a push-net at low-water mark.

2. The 0-group plaice first arrive in late April or May and recruitment continues into July or August. In the succeeding months, the mortality rate is about $40 \%$ per month. 0 -group dabs arrive in June and their monthly mortality rate is about $44 \%$.

3. Growth rate of plaice and dabs is high in summer but low from November to April.

4. The food of the earliest 0 -group plaice differed from year to year and included both plankton and benthos.

5. Pairs of fish species having similar feeding habits could be discerned but one of each pair had a wider depth distribution than the other. Plaice and dabs had similar diets but, when examined in detail, differences were apparent. 
6. Marking experiments indicated that, in summer and autumn, 0 -group plaice tended to keep to their own part of the bay and that, if transported offshore, they returned to the shallow-water areas.

\section{LITERATURE CITED}

Bregnballe, F., 1961. Plaice and flounder as consumers of the microscopic bottom fauna. Meddr Danm. Fisk.-og Havunders. (N.S.) 3 (6), 133-182.

Foerster, R. E. \& Ricker, W. E., 1941. The effect of reduction of predacious fish on survival of young sockeye salmon at Cultus Lake. J. Fish. Res. Bd Can. 5, 315-336.

JoNes, N. S., 1950. Marine bottom communities. Biol. Rev. 25, 283-313.

- 1952. The bottom fauna and the food of flatfish off the Cumberland coast. J. Anim. Ecol. 21, 182-205.

Pearcy, W. G., 1962. The ecology of an estuarine population of winter flounder, Pseudopleuronectes americanus (Walbaum). Bull. Bingham oceanogr. Coll. 18 (1), 1-78.

Ramster, J. W., 1965. The circulation of the eastern Irish Sea. C. M. Int. Council Expl. Sea (Hydrogr. Commn) Doc. No 99.

Riley, J. D., 1966. Liquid latex marking technique for small fish. J. Cons. perm. int. Explor. Mer 30, 354-357.

SaIla, S. B., Horton, D. B. \& Berry, R. J., 1965. Estimates of the theoretical biomass of juvenile winter flounder, Pseudopleuronectes americanus (WALBAUM) required for a fishery in Rhode Island. J. Fish. Res. Bd Can. 22 (4), 945-954.

\section{Discussion following the paper by MACER}

Greve: Have you noticed a decline of the population at the appearance of Pleurobrachia pileus? This ctenophore feeds on plaice larvae and the copepods which you found in your food investigations. Or did you never notice these ctenophores?

MACER: Pleurobrachia is abundant at certain times in the bay and we have been suspicious about its possible predation on plaice larvae and small juveniles. In the Pleurobracbia examined, very few had recognizable fish remains in their stomachs.

GREvE: I am primarily interested in possible quantitative correlations between abundance of plaice larvae and Pleurobrachia in different years.

MACER: Yes, it would be interesting to correlate abundance of larvae and juveniles with abundance of predators such as ctenophores. The whole question of factors determining yearclass strength is the subject of intensifying interest.

Lakkis: J'ai compris que dans votre analyse du contenu stomacal du Pleuronectes platessa adulte, vous avez donné des listes d'espèces ou de groupes assez précis, je comprends par là que le contenu stomocal devrait être dans un état assez net pour permettre de l'analyser; est ce qu'il en est de même pour les poissons pélagiques? Comment vous procédez pour faire telle analyse?

MACER: I found that, provided the fish were preserved soon after capture, the stomach contents were, in most cases, easily recognizable. In Decapoda, however, the stomach contents were more difficult to recognize. Very few pelagic fish were caught in my investigation, but, in those which I examined, the stomach contents were easily recognized.

Fonds: Can you comment on the influence of water temperature on the growth of the young plaice? 
MACER: Water temperature is, of course, important and will have to be taken into account in future work an energy flow. There are other factors - for example, density of food and density of young plaice.

Fonds: How about the effects of currents and the ability to smell food in relation to rheotactic behaviour of the plaice in homing?

MACER: Laboratory experiments are needed to investigate this problem. My observations have been confined to the field at present. 